\title{
UPAYA MENINGKATKAN KETERAMPILAN BERBICARA BAHASA INDONESIA MELALUI PENERAPAN METODE DEBAT PADA SISWA KELAS V SDN 09 MATTEKKO KECEMATAN BARA KOTA PALOPO
}

\author{
Ni'ma Zainuddin \\ INSTITUT AGAMA ISLAN NERGRI PALOPO \\ Jl. Agatis Balandai Kota Palopo \\ E-mail: nimazainuddin22194@gmail.com
}

\begin{abstract}
The research by using the method of debate aims to improve speaking skill on the students of grade V SDN 09 mattekko. This type of research is classroom action research (CAR). The subjects were teachers and students of class V SDN 09 Mattekko Kecamatan Bara Palopo city which amounted to 24, 10 men and 14 women. Research kurt lewin model has four stages of planning, implementation, observation, and reflection. Data collection using objective test method, that is by measuring students' speaking skills and observation method using observation sheet which aims to observe student activity and guidance. Qualitative and quantitative approaches are used to analyze collected data. From the research result of debate method can improve speech skill of class V student SDN 09 Mattekko. This is addressed by an increase in the average value. The number of students reaching the minimum criterion score (MCS) on the preeclosure test is $29.17 \%$, the first cycle is $58.33 \%$, and the second cycle is 95.83\%. While the average value of pratindakan 63.75, 68,09 cycle I, and cycle II 77.33. Success in this process can be seen from the liveliness and enthusiasm of students in following the process of learning activities, in this case, students have dared to issue ideas and respond to any existing answers and questions from opposing groups.
\end{abstract}

Keywords: Bahasa Indonesia, Speaking Skills, Debate Method

\begin{abstract}
Abstrak
Penelitian dengan menggunakan metode debat bertujuan untuk meningkatkan keterampilan berbicara pada siswa kelas V SDN 09 mattekko. Jenis penelitian ini adalah penelitian tindak kelas (PTK). Subyekpenelitian yaitu guru dan siswa kelas V SDN 09 Mattekko Kecamatan Bara kota Palopo yang berjumlah 24, 10 orang laki-laki dan 14 orang perempuan. Penelitain model kurt lewin memiliki empat tahap yaitu perencanaan, pelaksanaan, observasi, dan refleksi. Pengumpulan data menggunakan metode tes objektif, yaitu dengan mengukur keterampilan berbicara siswa dan metode observasi menggunakan lembaran observasi yang bertujuan untuk mengamati aktifitas siswa dan gu ru. Pendekatan kualitatif dan kuantitatif digunakan untuk menganalisis data yang terkumpul. Dari hasil penelitain metode debat dapat meningkatkan keterampilan berbicara siswa kelas V SDN 09 Mattekko. Hal ini ditujukan dengan adanya peningkatan nilai rata-rata. Jumlah siswa yang mencapai nilai kriteria ketuntasan minimal (KKM) pada tes prasiklus 29,17\%, siklus I sebesar 58,33\%, dan siklus II sebesar 95,83\%. Sedangkan nilai rata-rata pratindakan 63,75, siklus I 68,09, dan siklus II 77,33. Keberhasilan dalam proses ini dapat dilihat dari keaktifan dan antusias siswa dalam mengikuti proses kegiatan pembelajaran, dalam hal ini, siswa sudah berani mengeluarkan ide serta menanggapi setiap ada jawaban yang ada serta pertanyaan dari kelompok lawan.
\end{abstract}

Kata Kunci,: Bahasa Indonesia, Keterampilan Berbicara, Metode Debat. 


\section{PENDAHULUAN}

Bahasa resmi Republik Indonesia yaitu bahasa Indonesia itu sendiri yang merupakan alat komunikasi digunakan oleh bangsa Indonesia sebagai alat berkomunikasi. Pembelajaran bahasa Indonesia merupakan salah satu pelajaran yang wajib ada disetiap sekolah yang ada dilndonesia. Pada pembelajaran bahasa Indonesia memiliki empat keterampilan yang harus dikuasai siswa, yaitu keterampila1) mendengar atau menyimak (listening skills), 2) berbicara (speaking skill), membaca (reading skill) dan menulis(writing skill).yangmemiliki manfaat masing-masing. Nida dalam Tarigan (1981:1). "Bahasa merupakan produk budaya yang berharga dari generasi ke genarasi berikutnya. Bahasa adalah hasil budaya yang hidup dan berkembang yang haris dipelajari, seoranga anak manusia yang tidak pernah diajar berbicara, maka tidak akan pernah memiliki kemampuan berbicara". Zulela ( 2013:3). Sedangkan bahasa menurut woster's Thirt New International Dictionari of the English Languare dalam buku Sukirman Nurjan dan Edhy Rustan "Bahasa adalah alat yang sistematis untuk menyampaikan gagasan atau perasaan dengan memakai tanda-tanda, bunyibunyi, gesture, atau tanda-tanda yang disepakati, yang mengandung makna yang dapat dipahami". (2010:2)

Keterampilan berbicara adalah kemampuan seseorang dalam penyampaikan sustu informasi, suatu gagasan atau pikiran mengenai perasaan kepada seseorang atau kelompok secara lisan baik berbahasa lisan maupun jarak jauh. Akan tetapi jika menyampaiakn sustu pesan kepada orang lain degan menggunakan bahasa tulis, hendaknya memperhatikan setiap kata dan simbol, agar si penerima pesan dapat memahaminya dengan baik serta makna dari kalimat tersebut tidak mengalami perubahan. Kesalahan dalam penulisan dapat menyebabkan kerancuan kalimat yang berujung pada kesalahan penafsiran pembaca (Rustan, 2016). Anda dituntut untuk memiliki bekal keterampilan berbicara agar sewaktu-waktu diperlukan dapat menyampaikan sustu informasi kepada orag lain dengan baik. Kundharu dan Slamet (2014:51). Keterampilan berbicara merupakan hal terpenting dalam kehidupan seseorang, tanpa keterampilan berbicara seseorang akan merasa sulit dalam menyampaikan sustu informasi kepada orang lain. Menurut Hafiied Cangar (2009:4) Komunikasi adalah salah satu aktivitas yang sangat fundamental dalam kehidupan ummat manusia. Komunikasi membantu anak menyampaikan pesan dan mengekspresikan emosi tertentu untuk merespon keadaan lingkungan melalui kata-kata (Rustan \& Subhan, 2018). Sedangkan fungsi komunikasi menurut Daddy Mulyana (2014:5) "Fungsi komunikasi sebagai komunikasi sosial setidaknya 
mengisyaratkan bahwa komunikasi penting untuk membangun konsep diri kita, aktualisasi diri, untuk kelangsungan hidup, memperoleh kebahagiaan, terhindar dari tekanan dan ketegangan, antara lain lewat momunikasi yang menghibur, dan memupuk hubungan denga orang lain".

Meurut Aat Syafaat yang dikutip oleh Syamsu S Kata metode berasal dari bahasa latin yaitu "mete dan hodos. Meta berarti melalui, dan hodos berarti jalan atau cara. Sedangkan pengertian metode dalam konteks umum yaitu cara melakukan sesuatu kegiatan atau pekerjaan dengan menggunakan fakta dan konsep secara sistematis" (Syamsu S, 2017:79). Jika metode diterapkan oleh guru diseolah maka metode adalah suatu cara atau jalan yang dilakuan seorang guru untuk memahami objek permasalahan yang bersangkutan.

Metode debat yaitu salahsatu metode pembelajaran yang sangat diperlukan untuk meningkatkan kemampuan berbicara siswa. Debat adalah model pembelajaran di mana terdapat dua regu pada proses pembelajaran yang mempertahankan argumentasi tiap-tiap anggotanya terhadap satu topik. Sintaks metode pembelajaran adalah peserta didik dibagi menjadi dua kelompok yang saling duduk berhadapan, kemudian peserta didik mulai membaca materi yang akan disimak oleh masing-masing kelompok, presentase hasil bacaan yang ditanggapi oleh salahsatu perwakilan kelompok lainnya secara bergantian dan guru memberikan bimbingan untuk membuat kesimpulan. Sri Fatmawati dkk, (2015:27). Metode ini sangant baik digunakan dalam melatih keterampilan berbicara siswa agar siswa teransang untunk menanggapi pendapat kelompok lain dengan menggunakan idea tau pikirannya.

Berdasarkan pra tindakan yang dilakukan oleh penulis pada SDN 09 Mattekko Kecematan Bara Kota Palopo yaitu Permasalahan pada observasi awal yang peneliti temukan diantaranya rendahnya keterampilan berbicara siswa dan siswa merasa malu dalam menyampaikan ide atau pendapatnya. Sehingga peneliti memilih metode debat yang dapat melatih keterampilan berbicara siswa serta memberikan motivasi sehingga siswa tertarik untuk menaggapi pendapat kelompok lain dengan mengeluarak ide atau pikirannya sendiri. Untuk mengetahui sejau mana pemahaman siswa terhadap materi yang diberikan yaitu dengan melakukan observasi dan memberikan tes awal. Dari 24 siswa yang menjadi sampel sekaligus ikut dalam melakukan tes awal ternyata 11 siswa yang mendapat nilai termasuk kategori cukup, 5 siswa termasuk kategori kurang, dan 1 siswa termasuk kategori kurang sekali dan mendapatkan nilai rata-rata 63,75. 


\section{2 | Ni'ma Zainuddin}

Alasan tersebut mendorong peneliti untuk melaksanakan penelitian dengan menggunakan metode Debat untuk meningkatkan keterampilan berbicara siswa. Dalam menerapkan metode debat, ada bebrapa langakahlangkah diperhatikan antara lain:"1) Guru membagi siswa menjadi dua kelompok peserta debat, yang satu pro dan yang lainnya kontra, 2) Guru memberika tugas untuk membaca materi yang akan diperdebatkan oleh dua kelompok terdebut, 3) Guru menunjuk salah satu anggota pro untuk berbicara saat itu, kemudian ditanggapi oleh kelompok kontra. Demikian seterusnya sanpai sebagain peserta didik bisa mengemukakan pendapatnya. Sementara peserta didik menyampaikan gagasanya, guru menulis ide-ide dari setiap pembicaraan sampai mendapatkan sejumlah ide yang diharapkan, 4) Guru menambahkan konsep atau ide yang belum terungkap, 5) Dari datadata yang diungkapka tersenut, guru mengajak peserta didik membuat kesimpulan atau rangkuman yang mengacu pada topik yang ingin dicapai, 6) Guru membimbing siswa untuk membuat kesimpulan sesuai materi yang dibahas". Sri Fatmawati dkk (2015:27). Dengan adanya langkah-langkah ini memudahkan seorang guru dalam melaksanakan metode ini. Jika seseorang terampil dalam berbicara dia tidak akan merasa kesulitan dalam berkomunikasi dengan orang lain baik secara langsung (tatap muka) atau pun dengan jarak jauh. Hal ini sejalan dengan pendapat Anwar Arifin (2008:30) Pendidikan dapat disalurkan dengan berbagai cara yang salah satunya adalah dengan berbicara. Di dalam ilmu komunikasi, berbicara termasuk dalam komunikasi langsung (tatap muka), dipelajari dibawa namakomunikasi bicara (speech communication).

Kemampuan berkomunikasi ini membuat manusia berbeda dengan mahluk lainnya yang ada di bumi ini manusia berkomunikasi karena: 1) Manusia tidak bisa hidup sendiri, 2) Manusia berkomunikasi dengan orang lain untuk menyampaikan pikiran, gagasan atau perasaannya. Yusal Iriantara dan Asep Syaripuddin (2013:5).Seseorang yang memiliki kemampuan berbicara akan lebih mudah dalam menyampaikan ide atau gagasan kepada orang lain, keberhasilan menggunakan ide itu sehingga dapat diterima oleh orang yang mendengarkan atau yang diajak berbicara. Sebaliknya, seseorang yang kurang memiliki kemampuan berbicara akan mengalami kesulitan dalam menyampaikan ide gagasan kepada orang lain.Kundharu Saddhono dan Slamet (2014:52). Dalam pembelajaran Bahasa Indonesia sangat erat hubungannya dengan komunikasi dan interaksi. Siswa seringkali susah dalam mengeluarkan kata-kata pada saat diberikan kesempatan untuk mengutarakan pendapatnya. Dalam hal ini kita sebagai guru harus pandai dalam memotivasi siswa agar berani dalam mengucapkan /mengemukakan pendapatnya di depan teman-temannya maupun di depan umum.

PiJIES: Pedagogik Journal of Islamic Elementary School 
Berdasarkan pemaparan mengenai model pembelajaran debat tersebut, dapat dipahami bahwa debat adalah suatu argumen yang di lakukan oleh 2 kelompok atau lebih, dimana masing-masing kelompok mempertahankan pendapatnya dan menanganggapi bahwa pendapatnyalah yang paling benar dengan alasan yang masuk akal. Dalam berdebat, yang paling ditonjolkan adalah kecerdasan mencari alasan dan kecerdikan mempermainkan kata-kata sehingga lawan tidak mampu berkutik.

\section{METODE PENELITIAN}

Jenis penelitian yang digunakan adalah penelitian tindakan kelas (PTK) yang menggunakan pendekatan kualitatif dan kuantitatif. "Penelitian tindak kelas (PTK) adalah penelitian tindakan yang dilakukan dengan tujuan memperbaiki mutu praktik pembelajaran di kelas". Kunandar (2011:45). Penelitian tindak kelas (PTK) merupakan penelitian yang berteujuan untuk memperbaiki mutu setiap pembelajaran yang di kelas.Penelitian tindak kelas ini juga dapat menjembatani kesenjangana ntara teori dan praktek pendidikan. Sukidin, Basrowi, Suranto. (2010:15).Menurut Cohen dan Monion, "penelitian tindakan kelas mempunyai lima kategori fungsi, yaitu :

1) Sebagai alat untuk memecahkan masalah yang dilakukan dengan diagnosis dalam situasi tertentu. 2) Sebagai alat pelatihan dalam jabatan sehingga membekali yang bersangkutan dengan keterampilan, metode dan teknik mengajar yang baru, mempertajam kemampuan analisisnya dan mempetinggi kesadaran atas kelebihan dan kekurangan pada dirinya. 3) Sebagai alat untuk mengenalkan pendekatan tambahan atau inovatif pada pengajaran. 4) Sebagai alat untuk meningkatkan komunikasi antara guru di lapangan dan peneliti akademis, serta mmpernaiki kegagalan penelitian tradisional. 5) Sebagai alat untuk menyediakan alternatif atau pilihan yang lebih baik untuk mengantisipasi pendekatan yang lebih subjektif , impresionistik dalam memecahkan masalah di dalam kelas". Muhadi (2011:62). Kelima kategori penelitian tindak kelas ini merupakan sebuah alat untuk meningkatkan kinerja sorang guru dalam mengerjakan tugastugasnya. Dari jenis penelitian yang dipilih, maka penelitian menerapkan model penelitian tindakan dari Kurt Lewin, peneliti menggunakan model Kurt Lewin karna model Kurt Lewin merupakan model yang peneliti aggap mudah yaitu ia menjelaskan bahwa ada hal harus dilakukan dalam proses penelitin tindakan yakni perencanaan, tindakan, observasi, dan refleksi. Pelaksanaan penelitian tindakan adalah proses yang terjadi dalam satu lingkaran yang terus-menerus. 
Penelitian ini dilaksanakan di SDN 09 Mattekko kec.

Bara, Kota Palopo.

1) Sumber Data, pada penelitian ini peneliti menggunakan dua jenis data untuk mendukung penelitiannya adalah: a) Data primer adalah Observasi dengan pihak sekolah terkhususnya kepala Sekolah dan guru kelas V SDN 09 Mattekko. b) Data sekunder iayalah data yang didapatkan dari data tertulis berupa profil sekolah, data guru, data siswa, serta sarana dan prasarana yang ada di sekolah tersebut yang dibutuhkan untuk kelengkapan dalam penelitian. 2) Subjek Penelitian, Subjek penelitian adalah siswa-siswi kelas V SDN 09 Mattekko Kota Palopo, berjumlah 24 siswa yang terdiri dari 10 laki-laki dan 14 perempuan pada semester ganjil tahun pelajaran $2017 / 2018$.

Pengelolaan data dilakukan setelah terkumpulnya data pada penelitian. Selanjutnya dianalisis secara kuantitatif dan kualitatif. Untuk analisis secara kualitatif dan kuantitatif. Untuk analisis secara kuantutatif digunakan analisis secara statistik deskriptif yaitu skor rata-rata dan persentase.Sedangkan analisis kualitatif dilakukan terhadap data yang diperoleh melalui observasi aktivitas belajar siswa dan guru dalam penerapan Metode Debat untuk meningkatkan keterampilan berbicara siswa. Analisis ini dihitung dengan menggunakan rumus statistik sederhana, Suharsimi (2002:264) $\mathrm{RX}=\left(\sum \mathrm{X}\right) / \mathrm{N}$ menjumlahkan semua nilai yang diperoleh siswa selanjuatnya dibagi dengan jumlah siswa sehingga diperoleh nilai rata-rata, dari hasil penelitian yang telah didapatkan tersebut kemudian diklasifikasikan kedalam bentuk penskoran nilai siswa degan megguakan kriteria standar penilaian. Anas Sudijono (2009:43) rumus untuk mencarai frekuensi P=f/N x 100\% bila target kategori tuntas $80 \%-100 \%$ dan subyek $<40 \%$ berada dalam kategori tidak tuntas.

\section{HASIL DAN PEMBAHASAN HASIL PENELITIAN}

Setelah peneliti menerapkan metode Debat pada pelajaran bahasa Indonesia utuk meningkatkan keterampilan berbicara siswa kela V SDN 09 Mattekko Kecematan Bara Kota Palopo dapat diketahui bahwa aktivitas belajar siswa selalu meningkat. Hala ini dapat diketahui berdasarkan hasil observasi yang dilakukan pada setiap pertemuan mulai dari prasiklus, siklus I, dan siklua II. Peningkatan dapat digambarkan pada diagram sebagai berikut. 


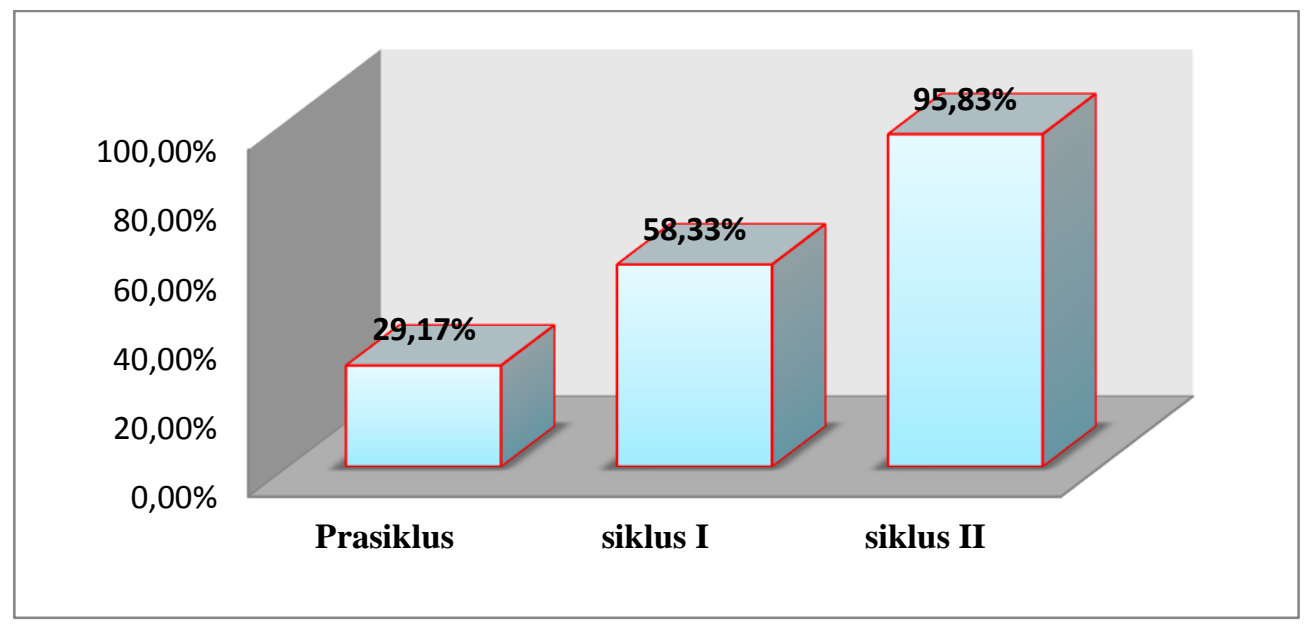

Diagram Hasil Tes Evaluasi Siswa

Data awal siswa menunjukkan bahwa keterampilan berbicar siswa kelas V SDN 09 mattekko Kecematan Bara Kota Palopo belum cukup untuk memenuhi nilai KKM. dengan alasan tersebut mendorong peneliti untuk melaksanakan penelitian dengan menggunakan metode debat untuk meningkatkan keterampilan berbicara siswa. Berdasarkan hasil deskriptif tabel diatas menunjukkan bahwa secara rekapitulasi pada tes hasil belajar siswa selalu meningkat. Setelah dilakukan dua siklus, ditinjau secara klasikal peningkatannya adalah $29,17 \%$ pada tes awal dengan nilai rata-rata 63,75 , kemudian meningkat menjadi $58,33 \%$ pada siklus I dengan nilai rata-rata 68,09 , dan pada siklus II meningkat menjadi 95,83\% dengan nilai rata-rata 77,33. Jadi, penerapan metode debat pada pemebelajaran dapat meningkatakan keterampilan berbicara siswa.

\section{PEMBAHASAN}

Pembahasan hasil penelitian terdiri dari aktivitas siswa dan guru dalam pembelajaran keterampilan berbicara dengan menerapkan metode debat pada siswa kelas V SDN 09 Mattekko kecematan Bara Kota Palopo.Pelaksanaan pembelajaran terdiri dari 4 langkah pembelajaran yaitu: 1) Tahap menyampaikan tujuan pembelajaran, 2) Tahap menjelaskan prosedur penggunaan metode debat, 3) Tahap melaksanakan pembelajaran keterampilan berbicara, dan 4) Tahap mempertahankan argument atau ide. Keempat langkah tersebut dirangkum menjadi tiga kegiatan yaitu: 1) Kegiatan awal, 2) Kegiatan inti, dan 3) Kegiatan akhir.Langkah-langkah pembelajaran yang dilakukan adalah mengamati berbagai macam benda kongkrit yang digolongkan oleh siswa.Aktivitas yang dilakukan siswa yaitu melakukan pembelajaran dengan menggunakan metode debat.Sebelum kegiatan ini dilakukan, terlebih dahulu guru mengecek pemahaman yang telah dimiliki siswa.Setelah itu, siswa melanjutkan aktivitasnya dengan 


\section{6 | Ni'ma Zainuddin}

melakukan perdebatan dengan mengeluarkan pendapat atau idenya masingmasing.

Berdasarkan hasil observasi yaitu kemampuan dalam melaksanakan pembelajaran menggunakan metode debat, bersama rekan sejawat dilakukan refleksi bahwa terdapat beberapa indikator yang harus diperbaiki terutama pada indikator membuat hipotesis, melakukan kegiatan verifikasi, melakukan aplikasi konsep, dan pemanfaatan waktu. Keempat indikator ini menjadikan catatan tersendiri yaitu dalam membuat hipotesis dibuat dalam bentuk sederhana sesuai dengan metode yang akan dilakukan. Verifikasi dilakukan harus sesuai dengan alat dan bahan serta berdasarkan hipotesis yang telah disusun. Aplikasi konsep yang harus dilakukan harus sesuai dengan materi pembelajaran, alat dan bahan.hipotesis yang disusun. Terpenting adalah pembatasan waktu, dalam pembatasan waktu yang harus ditentukan, yaitsu lamanya waktu berdebat dan dikarenakan dalam pembelajaran tidak dilakukan pembatasan waktu akibatnya ketika jam berakhir pembelajaran masih berlangsung. Hasil refleksi terhadap belajar siswa berdasarkan siklus I bahwa hasil pembelajaran perlu ditingkatkan dikarenakan perolehan nilai siswa yaitu nilai ratarata masih rendah. Masukan dalam diskusi antara guru dan rekan sejawat bahwa dalam pembelajaran pada kegiatan elaborasi dapat diinformasikan tentang materi pembelajaran. Berdasarkan hasil refleksi maka disimpulkan perlu tindakan lebih lanjut atau siklus II dengan melakukan penggantian submateri.

Berdasarkan pembelajaran tindakan siklusII peneliti sudah mampu melaksanakan pembelajaran secara optimal, dimana keempat tahapan pembelajaran dengan menggunakan metode debat sudah mampu diaplikasikan dengan baik, sehingga berdampak pada peningkatan pemahaman siswa dalam memahami materi, dimana pada tindakan siklus II ini pemahaman siswa dalam memahami materi sudah sesuai dengan yang diharapkan. Hal ini terlihat dari hasil tes evalusi siklus I dengan nilai ratarata 68,09 dan kriteria ketuntasan belajarnya mencapai 58,33\%, mengalami peningkatan pada siklus II yakni nilai rata-rata77,33 dengan kriteria ketuntasan belajarnya mencapai 95,83\%.

Tujuan pembelajaran yang telah ditetapkan telah tercapai dengan baik, siswa juga sudah mampu mengungkapkan argumen atau idenya masingmasing untuk mempertahankan pendapatnya. Pemahaman siswa mengenai materi yang diajarkan telah meningkat. Peningkatan juga terjadi karena adanya motivasi yang guru berikan kepada siswa, siswa merasa terangsang serta terdorong untuk melakukan kegiatan yang berhubungan dengan pembelajaran yang sedang berlangsung sehingga nilai rata-rata yang siswa dapatkan meningkata atau mengalami perubahan. Hal ini sejalan dengan

PiJIES: Pedagogik Journal of Islamic Elementary School 
pendapat David McClelland et al, yang dikutip oleh Hamzah B Uno (2015:9). yaitu "motif merupakan implikasi dari hasil pertimbangan yang telah dipelajari (redintegration) dengan ditandai suatu perubahan pada situasi afektif. Sumber utama munculnya motif adalah dari rangsangan (stimulasi) perubahan situasi sekarang dengan situasi yang diharapkan, sehingga tanda perubahan tersebut tampak pada adanya perbedaan afektif saat munculnya motif dan saat usaha pencapaian diharapkan, sehingga tanda perubahan tersebut tampak pada adanya perbedaan".

Selain pemberian motivasi guru juga memberika hadiah pada siswa yang mendapat nilai tertinggi pada akhir pembelajaran untuk membangkitkan semnagat belajar siswa. Seperti pendapat Mamiq Gaza (2012:88) teknik memberikan rewardatau bonus belajar menyenagkan bagi siswa yang berhasil menunjukkan prilaku posif-positif tertentu. Pendapat lain yang sama yaitu B.F Skinner (Sudarwan Danim Khair, 2014:107) siswa akan mengulangi prilaku yag diinginkan jika prilaku yang positif. Penguatan positif atau "imbalan" dapat mencakup penguatan verbal seperti "bagus", "bagus sekali", "sukses selalu”, "pertahankan prestasimu”, dan sebagainya.

Hal ini menunjukkan bahwa, penerapan metode debat adalah salah satu metode yang cocok diterapkan dalam meningkatkan keterampilan berbicara siswa terhadap mata pelajaran bahasa Indonesia. hal ini terlihat dari perubahan atau peningkatan nilai rata-rata yang di capai oleh siswa yaiti dari prasiklus 63,75 dengan ketuntasan 29,17\%, siklus I 68,09 dengan ketuntasan 58,33\%, dan siklus II 77,33 denga ketuntasan 95,83\%.

\section{PENUTUP}

Hasil analisis data penelitian, serta rumusan masalah maka dapat disimpulan bahwa:1)Setelah diadakan penelitian dengan penerapan metode debat pada siswa kelas V SDN 09 Mattekko Kecamatan Bara Kota Palopo lebih mudah untuk meningkatkan pembelajaran khususnya dalam keterampilan berbicara Bahasa Indonesia. 2) Dengan menggunakan metode debat dalam proses pembelajaran yang dilakukan secara bertahap yaitu dua siklus mengalami suatu peningkatan yang cukup signifikan dimana keterampilan berbicara siswa pada siklus I yang masihberkategori 'Cukup' dengan rata-rata 68,09 dengan ketuntasan belajar 58,33\% meningkat pada siklus II dengan kategori 'Baik' dengan rata-rata 77,33 dan ketuntasan belajar 95,83\%. Dengan demikian penerapan pembelajaran metode debat untuk peningkatan kerampilan berbicara siswa kelas V SDN 09 Mattekko Kecamatan Bara Kota Palopo. 


\section{DAFTAR PUSTAKA}

Arifin Anwar. 2008, Ilmu Komunikasi: Sebuah Pengantar Ringkas, Cet. I: Jakarta; PT Raja Grafindo Persada.

Arikunto Suharsimi.2002. Dasar-Dasar Evaluasi Pendidikan, Ed. Revisi. III; Jakarta: Bumi Aksara.

Cangara Hafied. 2009. Pengantara Ilmu Komunikasi, Ed. I-X; Jakarta: PT Raja Grafindo Persada.

Denim, Sudarwan. 2011. Pengantar Pendidikan. Cet. II. Bandung: Alfabeta.

Fatmawati Sri Dkk. 2015. Desain Laboratorium Skala Mini untuk Pembelajaran Sains Terpadu Cet:Yogyakarta.

Gaza Mamiq. 2012. Bijak Memghukum Siswa, Cet. I, Jokjakarta: Ar-ruzz Media.

Iriantara Yusal, SyaripuddinUsep. 2013Komunikasi pendidikan. Cet.I: Bandung; PT Remaja Rosdakarya.

Kunandar. 2011. Langkah Mudah Penelitian Tindakan Kelas Sebagai Pengembangan Profesi Guru, Cet.VII: Jakarta; PT Raja Grafindo Persada.

Muhadi. 2011. Penelitian Tindakan Kelas. Yogyakarta. Shira Media.

Muliyana Daddy. 2014. Ilmu Komunikasi, Suatu Pengantar, Cet. XVIII: Bandung; PT Remaja Rosdakarya.

Nida, Eugene A. 1957. Learning a foreign. Michigan, Ann Arbor: CushingMolly, Inc.

Nurdjan, S. dan Rustan, E. (2010). Kunci Sukses Berbahasa Indonesia. Lembaga Penerbitan STAIN (LPS) STAIN Palopo.

Rustan, E. (2016). Analisis Penggunaan Bahasa Indonesia Laras Hukum Pada Putusan Perkara Ekonomi Syariah Pengadilan Agama Makassar. AlAmwal: Journal of Islamic Economic Law, 1(2), 166-176. https://doi.org/10.24256/alw.v1i2.278

Rustan, E., \& Subhan. (2018). Komunikasi Verbal Anak Pesisir Usia 7-8 Tahun Pada Transakasi Penjualan Produk Kebudayaan Dengan Turis mancanegara. Jurnal Pendidikan Usia Dini, 12(1), 12-28. https://doi.org/10.21009/JPUD.121 02

S, Syamsu. 2017. Strategi Pembelajaran Tinjau Teori Praktis Bagi Mahasiswa dan Praktis Pendidikan, Cet I; Makassar; CV Nas Media Pustaka.

Saddhono Kundharu dan Slamet. 2014. Pembelajara Keterampilan Berbahasa Indonesia, Cet. I. Yogyakarta; Graha Ilmu,

Sudujono Anas. 2007. Pengantar Statistik Pendidikan, Ed. Ke-I; Jakarta: Raja Grafindo Persada.

Sukidin, Basrowi, Suranto. 2010. Menejemen Penelitian Tindakan Kelas, Cet, IV: Insan Cendekia. 
Uno, B, Hamsa. 2015. Teori Motivasi \& Pengukurannya Analisis Di Bidang Pendidikan, Cet. XII; Jakarta, PT Bumi Aksara.

Zulela. 2013. pembelajaran Bahasa Indonesia, Apresiasi Sastra di Sekolah Dasar, Cet,II: Bandung; PT Remaja Rosdakarya.ollan, Michael. The Omnivore's Dilemma: A Natural History of Four Meals. New York: Penguin, 2006.

Ward, Geoffrey C., and Ken Burns. The War: An Intimate History, 1941-1945. New York: Knopf, 2007. 
150 | Ni'ma Zainuddin

Halaman ini sengaja di kosongkan

PiJIES: Pedagogik Journal of Islamic Elementary School 